\title{
Synthesis and Ionophoric Properties of Crown Ether Capped with a Convergent Hydroxamic Acid Function
}

\author{
Duck Hee Kim, Mi Yee Kim, Byung Ha Kang, and Suk-Kỵu Chang \\ Department of Chemistry: Chang-Ang Lniversity, Seoul 156-756, Korea \\ Received October 31, 2001
}

Keywords : Crown ether. Hỵdroxamic acid. Transport $\mathrm{Cu}^{2-}$-selective ionophore.

The structures and functions of classical crown ethers have been continually evolved to meet the specific requirements for the recognition of more demanding target systems. ${ }^{1}$ One of the most frequently employ'ed approaches is the introduction of extra binding sites into the basic framework of crown ethers as are well-exemplified sy stems of the lariat crown ethers. ${ }^{2}$ Among these. lariat crown ethers having $\mathrm{pH}$-responsive functions in their arm. such as carboxylic acid and hydroxamic acid derivatives. are particularly attractive for the ionophoric applications. ${ }^{3}$ In particular. hydroxamic acid functions are employed frequently in many natural and sy'nthetic ionophore sỵstems and exhibited very' unique binding behaviors toward some transition metal ions. ${ }^{4.7}$ Meanwhile. in many of the designed supramolecular sy'stems. obtaining a specific convergent orientation of particular ligating functions toward active site is highly desirable for selective and strong binding of targeted guests. For these purpose. U-shaped structural motif of Kemp's triacid is known to be very useful and resulted in the developments of many sophisticated supramolecular sy stems. ${ }^{8-1 j}$ In this paper. we report the synthesis of a novel crown ether having a convergent hydroxamic acid function by utilizing the structural motif of Kemp's triacid and its selective ionophoric behavior toward some of heavy and transition metal ions in competitive transport experiments.

The hydroxamic acid derivative 3 was prepared from the
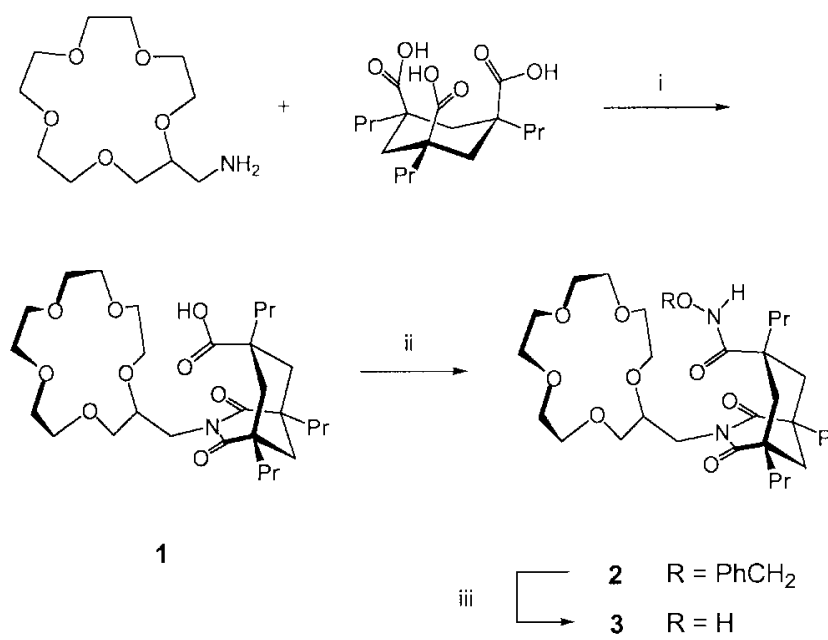

Scheme 1. Reagents and conditions: i, $200^{\circ} \mathrm{C}$; ii, oxalyl chloride in $\mathrm{CH}_{2} \mathrm{Cl}_{2}$, then $\mathrm{PhCH}_{2} \mathrm{ONH}_{2}, \mathrm{Et}_{2} \mathrm{~N}_{2} \mathrm{CH}_{2} \mathrm{Cl}_{2}$ : iii, $\mathrm{Pd} / \mathrm{C}, \mathrm{H}_{2}$ in $\mathrm{EtOH}$
Kemp's triacid-capped 15 -crown-5 ether 1 as shown in Scheme 1. Kemp's triacid-capped derivative 1 was prepared by the reaction of 2-aminomethyl-15-crown-5 ether ${ }^{11}$ with Kemp's triacid following the reported procedure. ${ }^{12}$ The acid derivative was converted into its acyl chloride by the treatment with oxalyl chloride. which was subsequently reacted with O-benzy lhydroxylamine $\left(\mathrm{CH}_{2} \mathrm{Cl}_{2} / \mathrm{NEt}_{3}\right)$ to yield benzyl derivative $2(60 \%)$. Deprotection of benzyl derivative by hydrogenation under $\mathrm{Pd} / \mathrm{C}$ condition ${ }^{12}$ afforded the desired hydroxamic acid derivative 3 in moderate vield $(85 \%)^{14}$ Due to the seemingly lower lipophilicity of the compound derived from methyl Kemp's triacid for an efficient carrier. propyl analogue of Kemp's triacid was employed for the constnuction of final ionophore structure. The enhancement in lipophilicity of the resulting propyl derivative 3 due to the replacement of three methyl groups of Kemp's triacid moiety with propyl groups is estimated to be 3.0 in Hansch's lipophilicity increment parameter $\left(\pi_{\mathrm{s}}\right){ }^{15}$ which we believe is much favorable and effective in transport efficiency compared with the derivative prepared from the methyl analogue of Kemp's triacid.

The hydroxamic acid derivative 3 was believed to exhibit quite diverse ionophoric belhavior compared with its carboxylic acid derivative 1 . The examination of CPK molecular model of 3 suggests that both the carbosylic acid and hydroxamic acid functions could have relatively convergent relationship with respect to the very plane of the crown ether moiety. In this situation. the complexed target metal ions can be efficiently stabilized both by the hydroxamate function and crown ether moiety. Furthermore, as is well known. the hydroxamate function in the prepared compound can act as a counter ion in addition to the ligating site for the guest metal ions. that is definitely favorable for the action as an efficient ionophore. ${ }^{16.17}$

The ionophoric properties of prepared compounds were investigated by the solvent extraction and transport experiments. To have a general idea about the ionophoric properties of 3. a preliminary solvent extraction experiment of metal ions from aqueous phase (buffered at $\mathrm{pH} 6$ with $\mathrm{HOAc} / \mathrm{NaOAc}$ ) into clloroform solution was performed. Extraction experiments were done under the competitive condition with a mixture containing alkali $\left(\mathrm{Li}^{+}, \mathrm{Na}^{+} . \mathrm{K}^{-}\right.$, $\left.\mathrm{Rb}^{-}\right)$, alkaline earth $\left(\mathrm{Mg}^{2-} \cdot \mathrm{Ca}^{2+} \cdot \mathrm{Ba}^{2-}\right)$, transition $\left(\mathrm{Co}^{2-}\right.$, $\left.\mathrm{Ni}^{2-} \cdot \mathrm{Cu}^{2+} \cdot \mathrm{Zn}^{3+}\right)$, and heavy metal ions $\left(\mathrm{Pb}^{2-}, \mathrm{Cd}^{2-}\right)$. As shown in Table 1. the hydroxamic acid $\mathbf{3}$ showed a selective 
Table 1. Extraction of metal ions into chloroform phase by 15-crown-5 ether ionophores"

\begin{tabular}{|c|c|c|c|c|c|c|c|c|c|c|c|c|c|}
\hline \multirow{2}{*}{ Ionophore } & \multicolumn{13}{|c|}{ Extraction efficiency (\%) } \\
\hline & $\mathrm{Pb}^{2+}$ & $\mathrm{Cd} \hat{\imath}^{-}$ & $\mathrm{Co}^{\hat{2}^{-}}$ & $\mathrm{Ni \hat {i } ^ { - }}$ & $\mathrm{Cu}^{\hat{u}^{-}}$ & $\mathrm{Zn}^{2-}$ & $\mathrm{Mg}^{2-}$ & $\mathrm{Ca}^{2-}$ & $\mathrm{Ba}^{2-}$ & $\mathrm{Li}^{-}$ & $\mathrm{Na}^{+}$ & $\mathrm{K}^{-}$ & $\mathrm{Rb}^{-}$ \\
\hline 1 & 51.6 & $-^{b}$ & $-^{b}$ & $-^{b}$ & $-{ }^{b}$ & $--^{b}$ & $-{ }^{4}$ & 1.7 & $-{ }^{4}$ & 4.7 & 6.5 & 4.8 & 3.1 \\
\hline 3 & 1.8 & $--^{b}$ & $--^{b}$ & $--^{b}$ & 20.6 & $--^{b}$ & $-{ }^{4}$ & 1.6 & -4 & 4.8 & 10.8 & 4.9 & 3.2 \\
\hline
\end{tabular}

"Extraction condition. Aqueous phase: a mixture containing 5.0 mmol each of metal acetates in $5.0 \mathrm{~mL}$ of NaOAc HOAc buffer ( $\mathrm{pH} 6)$. Organic phase: $5.0 \mathrm{~mm}$ ol of ionophore in $5.0 \mathrm{~mL}$ of $\mathrm{CHCl}_{3} .{ }^{b}$ Less than $1.0^{\circ} .0$.

Table 2. Transport of metal ions by 15 -crown-5 ether ionophores ${ }^{a}$

\begin{tabular}{|c|c|c|c|c|c|c|c|c|c|c|c|c|c|}
\hline \multirow{2}{*}{ Ionophore } & \multicolumn{13}{|c|}{ Transport efficiency (\%) } \\
\hline & $\mathrm{Pb}^{2-}$ & $\mathrm{Cd}^{2+}$ & $\mathrm{Co}^{2-}$ & $\mathrm{Ni}^{2-}$ & $\mathrm{Cu}^{2-}$ & $2 n^{2^{-}}$ & $\mathrm{Mg}^{1+}$ & $\mathrm{Ca}^{1+}$ & $\mathrm{Ba}^{2+}$ & $\mathrm{Li}^{+}$ & $\mathrm{Na}^{-}$ & $\mathrm{K}^{+}$ & $\mathrm{Rb}^{-}$ \\
\hline 1 & 12.6 & $-b$ & $--^{b}$ & $-b$ & 0.24 & $--^{b}$ & 0.52 & 0.35 & $--^{b}$ & $--^{b}$ & 2.1 & 0.23 & $-b$ \\
\hline 3 & 23.7 & $-b$ & 0.18 & $-b$ & 72.0 & 0.75 & $-b$ & $--^{b}$ & $-b$ & $-b$ & 2.2 & 0.26 & $-b$ \\
\hline
\end{tabular}

"Transport condition. Source phase: a mixture containing 5.0 mmol each of metal acetates in $5.0 \mathrm{~mL}$ of NaOAcHOAc bufter (pH 6). Membrane phase: $5.0 \mathrm{mmol}$ of ionophore in $15 \mathrm{~mL}$ of $\mathrm{CHCl}_{3}$. Receiving phase: $5.0 \mathrm{~mL}$ of $0.1 \mathrm{M} \mathrm{HNO}$. "Less than $0.1^{\circ}$.

extraction behavior toward $\mathrm{Cu}^{2+}$ ions among the surveyed metal ions of alkaline earth. transition. and heary metal ions. On the other hand, the carboxylic acid derivative 1 revealed quite efficient extraction behavior toward $\mathrm{Pb}^{2-}$ ions over other transition metal ions and alkaline earth metal ions. One thing to note is the relatively moderate extraction results of 1 and 3 toward alkali metal ions that might be originated from the intrinsic binding affinity of the 15-crown-5 ether moiety

Based on this extraction result. we next perfonned transport experiments of metal ions by the ionophores 1 and 3 through chloroform liquid membrane at $25^{\circ} \mathrm{C}$ using a standard U-tube apparatus (i.d. $=1.5 \mathrm{~cm}$ ). After transport of a mixture of alkali. alkaline earth. transition. and heavy metal ions from $\mathrm{pH} 6$ acetate buffer for $24 \mathrm{~h}$, an aliquot of the receiving phase was removed and the metal ion concentrations were determined by the inductively coupled plasmaatomic enission spectrometry (ICP-AES) (Table 2). Control experiment without any carrier in the membrane phase showed almost negligible transport efficiency toward all the tested metal ions. First thing to note is that the ionophore 3 showed a highly selective transport behavior toward $\mathrm{Cu}^{2+}$ ions. Transport selectivity toward $\mathrm{Cu}^{2+}$ over other transition metal ions is larger than 100 -fold. Compound 3 also showed a high selectivity for $\mathrm{Cu}^{i^{-}}$ions over alkali and alkaline earth metal ions of more than 138-fold and 167-fold in transport efficiency. respectively. This type of high transport selectivity toward $\mathrm{Cu}^{2+}$ ions has been reported for a podand type bis(hydroxamic acid) derivative by Bromberg et $a l^{1 /}$

To obtain more information about the role of hydroxamic acid function ${ }^{19.3}$ on the ionophoric properties of 3 , the transport behavior of closely related carboxylic acid derivative 1 was also investigated. Carboxylic acid 1 showed somewhat efficient transport behavior toward $\mathrm{Pb}^{2-}$ ions but very inefficient carrier properties toward most of the transition metal ions, alkaline earth metal ions. and alkali metal ions surveyed at the present experimental condition. Although a small selectivity toward alkaline earth metal ions of $\mathrm{Mg}^{--}$and $\mathrm{Ca}^{2-}$ ions are discernible, the transport efficiency is unsatisfactory for the application of $\mathbf{1}$ as a carrier for the separation of targeted metal ions.

In summary, the hydroxamic acid derivative 3 designed by conjugating the 15-crown-5 ether and Kemp's triacid motifs exhibited significantly selective and efficient transport behavior toward $\mathrm{Cu}^{2+}$ ions over other transition metal ions. This observation suggests possible applications of the present results for the selective removal and treatment of various toxic industrial waste effluents containing $\mathrm{Cu}^{3+}$ ions.

\section{Experimental Section}

General: ${ }^{1} \mathrm{H}$ NMR $(300 \mathrm{MHz})$ spectra were obtained by a Varian Gemini 2000 Spectrometer. ICP-AES measurements were performed on a Jovin Yvon JY-24. FAB-MS measurements were performed on a Micromass Autospec mass spectrometer. Propyl analogue of Kemp's triacid, 2-aminometlyy $1-15$-crown-5 ether. and $\mathrm{O}$-benzy lhydroxylamine were purchased from Aldrich $\mathrm{Co}$. and used without further purification.

Preparation of carboxylic acid 1. A mixture of Kemp s propyl triacid (343 $\mathrm{mg} .1 \mathrm{mmol}$ ) and 2-aminomethyl-15crownl-5 ether ( $250 \mathrm{mg} .1 \mathrm{mmol}$ ) was well mixed and heated at $200{ }^{\circ} \mathrm{C}$ for $3 \mathrm{~h}$ under $\mathrm{N}_{2}$ atmosphere. After cooling. the crude product was dissolved in $30 \mathrm{~mL}^{\circ} \mathrm{CHCl}_{3}$ and filtered. and the filtrate was evaporated under reduced pressure. The product was purified by the colunn chromatograply (silica gel. eluting with $3: 1$ hexane/EtOAc) to yield 1 as low melting solid (456 mg. 82\%); ${ }^{1} \mathrm{H}$ NMR (300 $\left.\mathrm{MHz} . \mathrm{CDCl}_{3}\right) \delta$ $3.89(\mathrm{~s}, 3 \mathrm{H}) .3 .78-3.62(\mathrm{~m}, 16 \mathrm{H}) .3 .64(\mathrm{q} . J=13.0 \mathrm{~Hz}, 2 \mathrm{H})$, $2.64(\mathrm{~d} . J=13.8 \mathrm{~Hz}, 2 \mathrm{H}) .2 .18(\mathrm{~d} . J=13.2 \mathrm{~Hz} .2 \mathrm{H}), 1.99(\mathrm{~m}$, $2 \mathrm{H}) .1 .45-1.24(\mathrm{~m}, \mathrm{l} 2 \mathrm{H}), 0.94(\mathrm{~m} .6 \mathrm{H}) .0 .88(\mathrm{t}, J=7.2 \mathrm{~Hz}$, $3 \mathrm{H})$; FAB MS ( $m$-NBA) $[\mathrm{M}+\mathrm{l}]^{+} 556.2(100 \%) .[\mathrm{M}+\mathrm{Na}]^{-}$ $578.2(71 \%),[\mathrm{M}+\mathrm{K}]^{-} 594.2(28 \%)$.

Preparation of benzyl ether 2. To a solution of compound 1 (228 mg. $0.5 \mathrm{mmol}$ ) in $\mathrm{CH}_{2} \mathrm{Cl}_{2}(5 \mathrm{~mL})$, oxalyl chloride $(0.18 \mathrm{~mL} .2 \mathrm{mmol})$ and a drop of DMF were added in sequence. The reaction mixture was stirred for $2 \mathrm{~h}$ at $\mathrm{rt}$. After complete evaporation of oxalyl chloride and $\mathrm{CH}_{2} \mathrm{Cl}_{2}$ under reduced pressure, the remaining solid was dissolved in 
$\mathrm{CH}_{2} \mathrm{Cl}_{3}$. To the solution of O-benzylhydroxylamine hydrochloride (100 mg. $0.63 \mathrm{mmol}$ ) and triethy lamine $(0.25 \mathrm{~mL}$. $1.8 \mathrm{mmol}$ ) in $\mathrm{CH}_{2} \mathrm{Cl}_{2}$ the acid chloride (in $\mathrm{CH}_{2} \mathrm{Cl}_{2}$ ) was added and heated at $40{ }^{\circ} \mathrm{C}$ under $\mathrm{N}_{2}$ atmosphere. After overnight stirring. the solution was filtered. and washed with $0.1 \mathrm{M} \mathrm{HCl}$. The organic layer was dried over $\mathrm{MgSO}_{4}$ and evaporated. The residue was purified by the column chromatograph (silica gel. eluting with $3: 1$ hexane/EtOAc) to yield 2 as low melting solid ( $396 \mathrm{mg}, 60 \%$ ). ${ }^{1} \mathrm{H}$ NMR $\left(300 \mathrm{MHz} . \mathrm{CDCl}_{3}\right) \delta 8.11(\mathrm{~s} . \mathrm{lH}), 4.78(\mathrm{~s} .2 \mathrm{H}), 3.84(\mathrm{~m}, \mathrm{lH})$. $3.76-3.60$ (m. $20 \mathrm{H}) .3 .46(\mathrm{~d} . J=4.5 \mathrm{~Hz} .2 \mathrm{H}) .2 .35$ (d. $J=$ $13.8 \mathrm{~Hz} .2 \mathrm{H}) .2 .14(\mathrm{~d}, J=13.2 \mathrm{~Hz}, 2 \mathrm{H}) .1 .96(\mathrm{~m}, 2 \mathrm{H}), 1.33-$ $1.10(\mathrm{~m}, 12 \mathrm{H}), 0.92(\mathrm{t} . J=6.8 \mathrm{~Hz}, 6 \mathrm{H}), 0.77(\mathrm{t}, J=7.2 \mathrm{~Hz}$. $3 \mathrm{H})$ : FAB-MS $(m-\mathrm{NBA})[\mathrm{M}+\mathrm{I}]^{+} 661.5(100 \%),[\mathrm{M}+\mathrm{Na}]^{+}$ $683.5(5 \%)$

Preparation of hydroxamic acid 3. Compound 2 (260 mg. $0.4 \mathrm{mmol})$ was dissolved in $\mathrm{EtOH}(25 \mathrm{~mL})$ and treated with $5 \% \mathrm{Pd} / \mathrm{C}(30 \mathrm{mg})$ under $\mathrm{l}$ atm of $\mathrm{H}_{2}$ for $2 \mathrm{~h}$ at rt. The reaction mixture was filtered and evaporated to give the desired compound 3 (194 mg, 84.5\%). ${ }^{1} \mathrm{H}$ NMR ( $300 \mathrm{MHz}$. $\left.\mathrm{CDCl}_{3}\right) \delta 3.81-3.47(\mathrm{~m}, 21 \mathrm{H}), 2.62(\mathrm{~d}, J=14.1 \mathrm{~Hz}, 2 \mathrm{H})$. 2.08-1.91 (m. $4 \mathrm{H}) .1 .36-1.13(\mathrm{~m}, 12 \mathrm{H}) .0 .92$ (t. $J=4.2 \mathrm{~Hz}$. $6 \mathrm{H}), 0.87(\mathrm{t} . J=7.2 \mathrm{~Hz}, 3 \mathrm{H})$ : FAB-MS $(m-\mathrm{NBA})[\mathrm{M}+\mathrm{l}]^{+}$ $571.4(100 \%)$. $[\mathrm{M}+\mathrm{Na}]^{-} 593.4(90 \%)$.

Extraction and transport experiments. The stock solution was a mixture of alkali, alkaline earth, transition, and heavy metal ions in acetate salts $(8.0 \mathrm{mM})$ in $\mathrm{HOAc} / \mathrm{NaOAc}$ buffer at $\mathrm{pH}$ 6. The aqueous metal solution $(5.0 \mathrm{~mL})$ was extracted with $\mathrm{CHCl}_{3}$ solution ([ionophore] $=4.0 \mathrm{mM}$. 5.0 $\mathrm{mL}$ ) at $25^{\circ} \mathrm{C}$. After the extraction the system was centrifuged to ensure the complete separation. The separated organic phase was back extracted with $\mathrm{I} \mathrm{M} \mathrm{HNO}_{3}$ and the extracted metal ions were analyzed by ICP-AES. Extraction efficiency was calculated by dividing the moles of metal ion extracted with the moles of ionophore. Transport experiments were performed as reported earlier. ${ }^{14}$ Extraction and transport experiments for mercury ions were not performed due to its relatively significant solubility in the organic phase under the present experimental condition.
Acknowledgment. This work was supported by a research grant from Chung-Ang University (2000) and gratefully acknowledged.

\section{References}

1. Cation Binding by Hacrocycles: Inoue. Y; Gokel, G. W. Eds.: Marcel Dekker: New York. 1990

2. Gokel. G. W. Crown Ethers and Chptands: The Royal Society of Chemistry: Cambridge. 1991

3. Brown, P. R.: Bartsch. In Inclusion Aspects of Hembrane Chemistry: Osa. T., Atwood, J. L.. Eds.: Kluwer: Dordrecht. 1991; pp 157.

4. Telford. J. R.: Raymond. K. N. In Conturhensive Supramolecular Chentistry Gokel. G. W.. Ed.: Pergamon: 1996: Vol. 1. Chap 6.

5. Nudelman1. R.: Ardont. O.: Hadar. Y.: Chen. Y: Libmant. I.: Shanzer. A. J. Hed Chem 1998. $11,1671$.

6. Nagasaki. T.; Shinkai, S. J. Chem. Soc. Perkin Trans. 21991. 1063 .

7. Canevet. C.: Libmat1. J.: Shatzer. A. Angew: Chent. Imt. Ed. Engt. 1996. 35. 2657

8. Marshall. L.: Parris. K.: Rebek. I. Jr: Luis. S. V.: Burguete. M. I. J. Am. Chem. Soc. 1988. 110, 5192.

9. Hirose. T.: Wang. Z-H.: Baldwin. B. W: Uchimaru, T.: Kasuga. K. Bull. Chem. Soc. Jpn. 1999,72.865.

10. Hirose. T.: Baldwin. B. W.: Wang. Z.-H.: Kasuga. K.: Uchimaru. T: Yliniemela. A. Chem. Commm. 1996. 391.

11. Bubnis. B. P.: Pacey. G. E. Tetrahedron Lett. 1984. 25. 1107

12. Cho, Y. H.: Chang. S.-K; Choe, J.-I. Bull Korean Chem Soc. 1996. 17,1099

13. Fages. F; Bodenant. B.: Weil, T. J. Org. Chem. 1996. 61. 3956.

14. Kiml. D.-H.: Choi. M. T.: Chang. S.-K. Bull. Korean Chem. Soc. 2001. 22.699.

15. Leo. A.: Hansch. C.: Elkins. D. Chen. Rev 1971. 71. 525

16. Elshani. S.; Noriyuki, R; Wai, C. M: Natale, N. R.; Bartsch. R. A. J. Heterocyclic Chem 1998, 35.875.

17. Elshani. S.: Du. H.; Laintz. K. E.: Natale, N. R.; Wai. C. M.: Elkarim. N. S. A.: Bartsch. R. A. Tetrohedron 2000. 56.4651 .

18. Bromberg. L.: Levit1. G.: Libman. T.: Shanzer. A. J. Membrone Sci. 1992. 69. 143.

19. Farkas. E.: Kozma, E; Pethõ. M.: Herlihy. K. M; Micera. G. Polvhedron 1998, 17.3331.

20. Farkas. E; Enyedy. E. A.; Micera G.; Garribba, E. Polyhedron 2000. 19.1727 . 